Article

\title{
Evaluation of Effects of the Humidity Level-Based Auto-Controlled Centralized Exhaust Ventilation Systems on Thermal Comfort of Multi-Family Residential Buildings in South Korea
}

\author{
Byung Chang Kwag, Jungha Park, Seongyong Kim and Gil Tae Kim * (1) \\ Center for Housing Environment Research and Innovation of the Korea Land and Housing Institute, \\ Sejong 30065, Korea \\ * Correspondence: gtkim1@lh.or.kr
}

Received: 1 August 2019; Accepted: 31 August 2019; Published: 2 September 2019

\begin{abstract}
Building air-tightness has been increased to make energy efficient buildings. However, various indoor air quality issues can be caused by high building air-tightness because it allows low air and moisture transmission through building envelop. In order to solve and prevent these issues, mechanical ventilation systems can be used to control the indoor humidity level. The purpose of this paper is to evaluate the performances of the Relative Humidity (RH)-sensor based auto-controlled centralized exhaust ventilation systems to manage indoor air quality and thermal comfort of multi-family residential buildings in South Korea. A series of field tests were performed for different target zones and for various moisture source scenarios. As a result, it was found that the auto-controlled centralized exhaust ventilation systems were able to control indoor air quality and to maintain the zones thermal comfort faster than the baseline cases that did not operate exhaust vents. The results presented in this paper can show the potential and the feasibility of the auto-controlled centralized exhaust ventilation systems for multi-family residential buildings in South Korea. It is expected that the results presented in this paper would be useful for building owners, engineers, and architects when designing building systems.
\end{abstract}

Keywords: centralized exhaust ventilation; humidity level; field tests; auto control; thermal comfort

\section{Introduction}

In South Korea, air-tightness has been an important energy conservation measure to have energy efficient multi-family residential buildings by reducing energy loads for space cooling and/or space heating. According to the Korea Energy Economics Institute, the energy consumption by the building sector accounts for 19\% of the total Korea energy use during 2017 [1], while it was more than $40 \%$ by the building sector in U.S. or European countries in the same period [2,3]. However, high air-tightness of buildings could cause various indoor air quality issues, such as condensation, mold, mildew and fungus, and thermal comfort of residents, because of low air exchanges between indoor and outdoor. Indeed, several pieces of research have shown the correlations between these issues and indoor humidity levels [4-8]. The higher building air-tightness allows the lower air and moisture transmission through building envelop.

In general, condensation occurs when the indoor air humidity level is not readily controlled and thus water vapor in the indoor air is accumulated around exterior walls and/or doors and windows. Condensation is closely associated with various factors, such as outdoor and indoor air conditions, building construction, and behavior of occupants. The effects of building construction factors, such as heat transfer through building envelop and thermal bridges, can be controlled by using proper building 
envelop insulations, and the effects of occupant behavioral factors on indoor humidity level can be managed by ventilation to exhaust humid indoor air generated by various activities, such as cooking, shower, or laundry [5].

In general, air temperature and humidity level largely affect thermal comfort, and there is a relationship between thermal comfort and enthalpy, which is bounded by air temperature and humidity level. Many researchers have shown that air temperature and humidity level are key variables when considering indoor thermal comfort [9-18]. Indeed, in Raczkowski's research [18], it was shown that as enthalpy increased, the acceptability of air quality decreased.

Some researchers have demonstrated the ability to control indoor humidity by removing moisture by performing experiments [19-22]. For instance, Lim et al. found from the experiments that the excessive water vapor generation could cause a condensation issue and that the indoor humidity level could be controlled and thus the condensation issue could be solved by ventilation systems [19]. Suh et al. performed experiments to evaluate the ability of humidity level control of the decentralized ventilation systems by exhausting indoor moisture to outside [20]. They observed that the dew point temperatures could be lowered when using ventilation systems. Kim et al. also showed the possibilities of the auto indoor humidity control system based on indoor air dew point and wall surface temperature embedded into energy recovery ventilator systems to manage indoor humidity ratio as well as to prevent condensation [21].

Nielsen et al. researched energy performances of demand controlled ventilation (DCV) for single family houses located in Denmark using the strategy based on $\mathrm{CO}_{2}$ level and moisture content in the outdoor air and exhaust air [22]. As a result, they showed the sensor-based DCV system could reduce the electricity consumption by $35 \%$ for fans while managing the $\mathrm{CO}_{2}$ level and moisture level in the house. In other words, using the sensor-based DCV system could save energy consumptions in ventilation systems while keeping indoor air quality.

However, to control indoor humidity level it would require energy to run exhaust vent fans of decentralized ventilation systems on demands. In order to save the energy consumed by exhaust ventilation systems, the public multi-family residential buildings provided by Korea Land and Housing Corporation ( $\mathrm{LH}$ ) that owned by Korean Government employed the centralized exhaust ventilation systems connected to a roof fan. Kim et al. performed a comparative analysis between centralized exhaust ventilation systems and decentralized exhaust ventilation systems to evaluate humidity control performances of kitchen vents [23]. According to their research, the amounts of humidity rise when using centralized exhaust ventilation systems were lower than those controlled by decentralized systems by $11 \sim 35 \%$ based on the flow rate of the vents and floor areas.

However, even though Kim et al. showed the feasibility of the centralized exhaust ventilation systems for multi-family residential buildings, their research was confined to kitchen vents. Besides, even though there have been several pieces of research about the ability of ventilation systems to remove moisture and to control indoor humidity level, as aforementioned most studies were carried out for decentralized ventilation systems. Therefore, there are needs to evaluate the performance of humidity control of centralized exhaust ventilations installed in other zones, such as vents in bathrooms and the laundry room, and also to study the ability of auto-controlled centralized exhaust ventilation systems to manage indoor humidity level to keep thermally comfort indoor environments. For these reasons, this study is designed to investigate the performances of relative humidity $(\mathrm{RH})$ sensor-based centralized exhaust ventilation systems to control the indoor humidity level and the effects on thermal comfort of a multi-family residential building.

\section{Methodology}

In this paper, a series of field tests were performed for a sample unit of a 5-story multi-family residential building located in Sejong-si, South Korea. This residential building as a test bed was built for researches and field tests designed upon one of the standard floor plans for LH public multi-family residential buildings. In this test building, the centralized exhaust ventilation systems were installed 
and connected with roof fans. The description of the test residential unit was provided in Tables 1 and 2, and the figures of the test building, a roof fan, and bathroom exhaust vent are provided in Figure 1. The flow rates of the exhaust vents were decided according to the LH specification for construction. As illustrated in Figure 2, a centralized exhaust ventilation system consisted of a centralized roof-fan-a vertical centralized air-duct that was always set to a negative pressure by the roof-fan-dampers, and exhausted air vents installed in each residential unit.

Table 1. Description of the test bed unit.

\begin{tabular}{cc}
\hline Floor area & $59 \mathrm{~m}^{2}$ \\
\hline Structure type & $\begin{array}{c}\text { Reinforced concrete structure } \\
\text { Load-bearing wall system }\end{array}$ \\
\hline Floor & Test unit on the 1st floor (Total 5 stories slab-on-grade) \\
\hline Exhaust ventilation type & Centralized exhaust ventilation connected to a roof fan \\
\hline Flow rate setup & Bath $1-80 \mathrm{~m}^{3} / \mathrm{h}$ \\
& Bath $2-80 \mathrm{~m}^{3} / \mathrm{h}$ \\
\hline
\end{tabular}

Table 2. Zone sizes of the test bed unit.

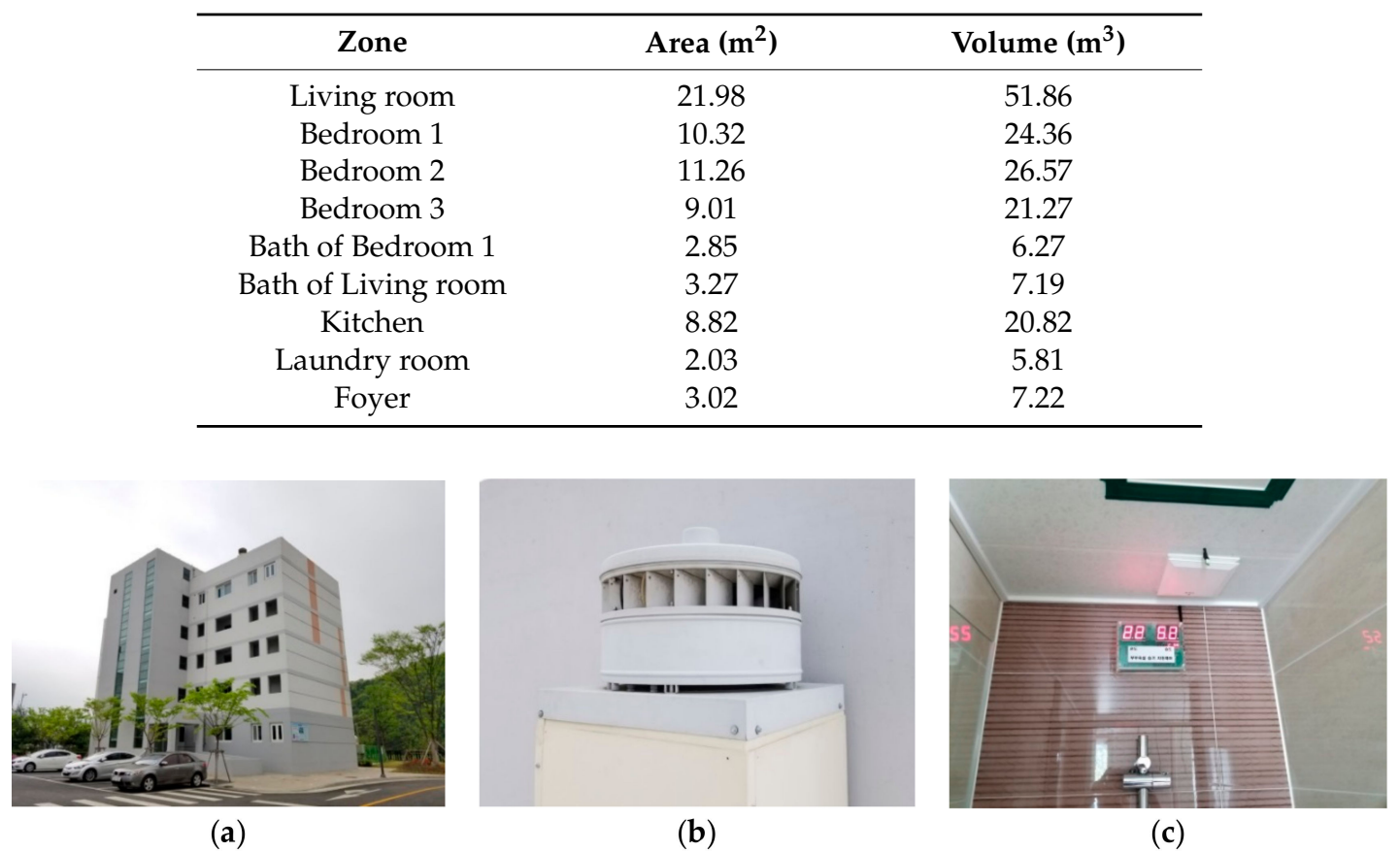

Figure 1. (a) Test bed building, (b) roof fan associated with the centralized exhaust ventilation system, and (c) relative humidity $(\mathrm{RH})$-sensor based auto-controlled bathroom exhaust vent. 


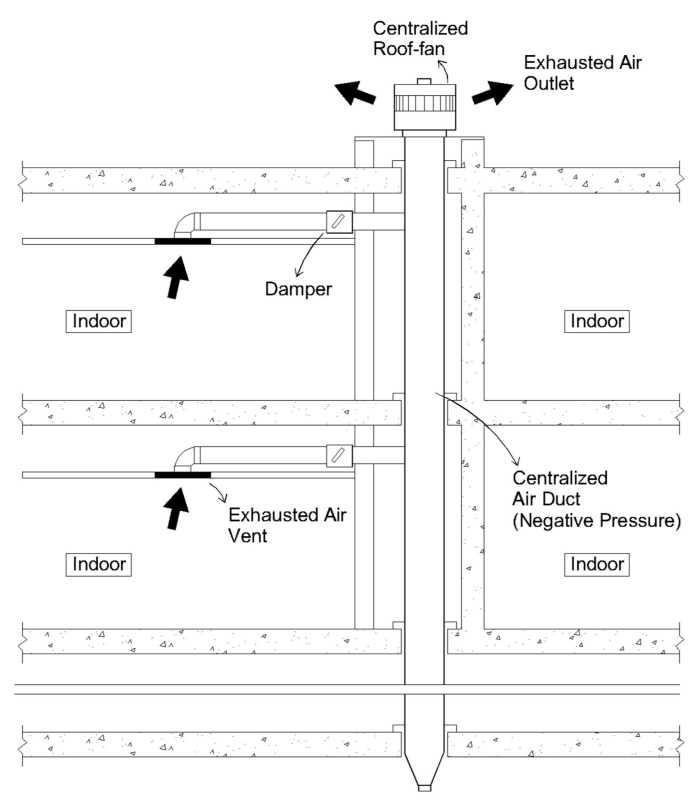

Figure 2. Schematic drawing of the centralized exhaust ventilation.

Since one of the main purposes of this research was to evaluate the performances of indoor humidity controls of the centralized exhaust ventilation systems, 2-channel data loggers were installed in every zone to monitor temperature and relative humidity changes. The specifications of the measuring equipment are provided in Table 3. Figure 3 provides the schematic flowchart of the $\mathrm{RH}$-sensor based auto-controlled exhaust ventilation system employed in this research. For each target zone, the baseline was the case without using an exhaust vent. Figure 4 provides the floor plan of the test unit and the schematic image of centralized exhaust ventilation systems, and the locations of the sensors.

Table 3. Specifications of measuring equipment.

\begin{tabular}{cc}
\hline Equipment & Specification \\
\hline Wireless 2-channel data logger & Range: $-20^{\circ} \mathrm{C}$ to $+60{ }^{\circ} \mathrm{C} / 0 \% \mathrm{RH}$ to $95 \% \mathrm{RH}$ \\
& Resolution: $0.01{ }^{\circ} \mathrm{C} / 0.1 \% \mathrm{RH}$ \\
& Accuracy: $\pm 0.5{ }^{\circ} \mathrm{C} / 2.0 \% \mathrm{RH}$ typical $@ 25{ }^{\circ} \mathrm{C}$ \\
\hline & Range: $-40{ }^{\circ} \mathrm{C}$ to $+120^{\circ} \mathrm{C} / 0$ to $100 \% \mathrm{RH}$ \\
Wired digital hygrometer & Resolution: $0.01{ }^{\circ} \mathrm{C} / 0.05 \% \mathrm{RH}$ \\
& Accuracy: $\pm 0.4{ }^{\circ} \mathrm{C} / \pm 3.0 \% \mathrm{RH}$ \\
\hline
\end{tabular}




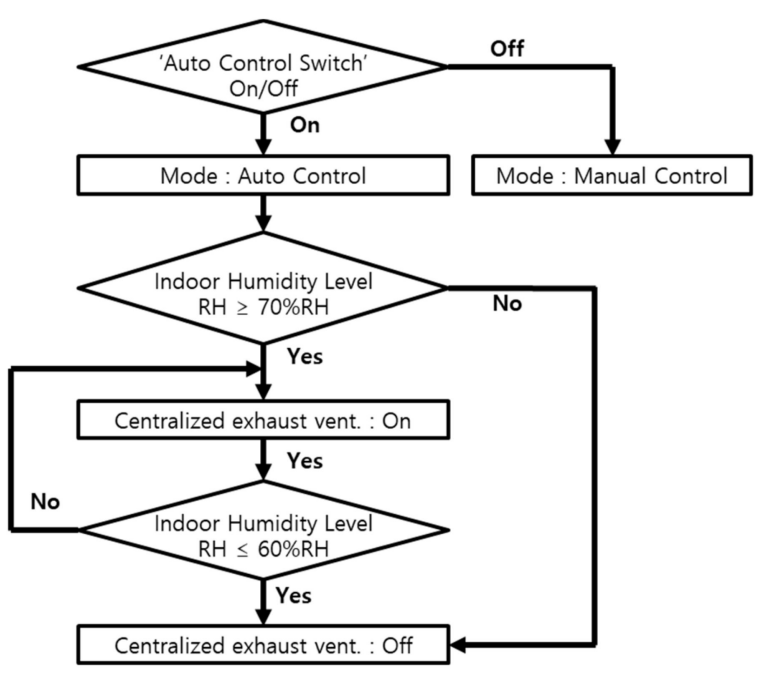

Figure 3. Flowchart of the RH-sensor based auto-controlled exhaust ventilation system.

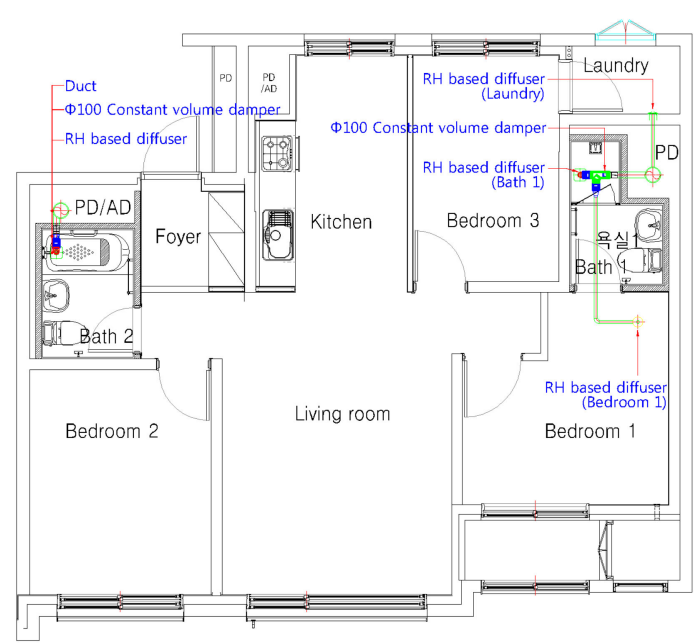

(a)

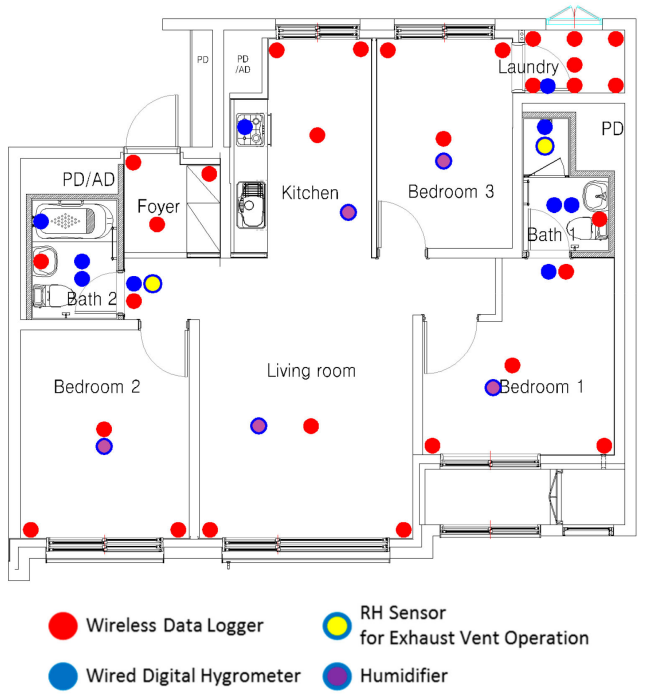

(b)

Figure 4. (a) Floor plan, and exhaust vents and ducts and (b) locations of measuring equipment.

\section{Field Tests}

A series of experiments were performed in the $59 \mathrm{~m}^{2}$ unit of the test building for different target zones to evaluate performances of centralized exhaust ventilation systems to control the indoor humidity level and to prevent condensation. The experiment settings are provided in Table 4 . The indoor ambient air temperature and relative humidity were controlled by the radiant heating floor and humidifiers, respectively. In order to minimize the impacts of outdoor air humidity, the experiments were performed in February through March. Table 5 presents the scenarios of the experiments for different target zones. 
Table 4. Description of experiment settings for different zones.

\begin{tabular}{|c|c|c|}
\hline Case & Target Zone & Settings \\
\hline Case 1 & Bedroom 1 and bath 1 & $\begin{array}{c}\begin{array}{c}\text { Spray hot water in the shower booth for } 15 \mathrm{~min} \\
\text { (Hot water temperature } 43.0^{\circ} \mathrm{C} \text { ) }\end{array} \\
\text { Open shower booth door and bathroom-1 door after the } \\
\text { shower } \\
\text { Monitor humidity changes based on exhaust vent } \\
\text { operation } \\
\text { Flow rate of exhaust vent: Bath } 1-60 \mathrm{CMH} / \text { Bedroom } \\
1-20 \mathrm{CHM} \\
\text { Exhaust vent operation: On RH } \geq 70 \% \mathrm{RH} \\
\text { Setpoint Temperature/humidity level: } 23^{\circ} \mathrm{C} / 60 \% \mathrm{RH}\end{array}$ \\
\hline Case 2 & Living room Kitchen Foyer & $\begin{array}{c}\text { Boil } 1 \mathrm{~L} \text { of tap-water for } 30 \mathrm{~min} \\
\text { Monitor humidity changes based on exhaust vent } \\
\text { operation } \\
\text { Flow rate of exhaust vent: Bath } 2-80 \mathrm{CMH} \\
\text { Exhaust vent operation: On } \mathrm{RH} \geq 70 \% \mathrm{RH} \\
\text { Setpoint Temperature/humidity level: } 23^{\circ} \mathrm{C} / 60 \% \mathrm{RH}\end{array}$ \\
\hline
\end{tabular}

Table 5. Field tests scenarios.

\begin{tabular}{ccccc}
\hline & Case 1-1 & Case 1-2 & Case 2-1 & Case 2-2 \\
\hline Exhaust Vent Operation & Off & On & Off & On \\
\hline
\end{tabular}

Since the experiments for all the cases were carried out for less than $3 \mathrm{~h}$ and the weather conditions were fine, the humidity ratios of the outdoor air were not significantly changed. For this reason, this study considered the average outdoor air data. Table 6 shows the average outside air temperature and relative humidity data during field tests. Using the measured data, this paper calculated the humidity ratio, which was also referred to the absolute humidity referring to the mass of water vapor per unit mass of dry air in $\mathrm{kg} / \mathrm{kg}$-dry air. As shown in Table 6, the differences in humidity ratio between Case 1-1 and Case 1-2, and Case 2-1 and Case $2-2$ were $0.00052 \mathrm{~kg} / \mathrm{kg}(12 \%)$, and $0.00002 \mathrm{~kg} / \mathrm{kg}$ $(1 \%)$, respectively. In addition, as the outdoor air was introduced into the indoor through infiltration, the influences of the outdoor air could be limited and not significant to the indoor humidity ratios.

Table 6. Average outside air conditions during field tests.

\begin{tabular}{cccccc}
\hline Target Zone & Activity & Case & $\begin{array}{c}\text { Outside Air } \\
\text { Measured } \\
\text { Temperature }\end{array}$ & $\begin{array}{c}\text { Outside Air } \\
\text { Measured Relative } \\
\text { Humidity }\end{array}$ & $\begin{array}{c}\text { Outside Air } \\
\text { Calculated Humidity } \\
\text { Ratio }\end{array}$ \\
\hline $\begin{array}{c}\text { Bedroom 1 and } \\
\text { bath 1 }\end{array}$ & $\begin{array}{c}\text { Shower in Bath } \\
1\end{array}$ & Case 1-1 & $5.3^{\circ} \mathrm{C}$ & $67 \% \mathrm{RH}$ & $0.00369 \mathrm{~kg} / \mathrm{kg}$ \\
\cline { 2 - 5 } $\begin{array}{c}\text { Living room } \\
\text { Kitchen Foyer }\end{array}$ & $\begin{array}{c}\text { Cook in } \\
\text { Kitchen }\end{array}$ & Case 1-2 & $10.4{ }^{\circ} \mathrm{C}$ & $54 \% \mathrm{RH}$ & $0.00421 \mathrm{~kg} / \mathrm{kg}$ \\
\cline { 3 - 6 } & Case 2-1 & $9.4{ }^{\circ} \mathrm{C}$ & $27 \% \mathrm{RH}$ & $0.00203 \mathrm{~kg} / \mathrm{kg}$ \\
\hline
\end{tabular}

\section{Results}

\subsection{Evaluation of Effects on Indoor Air Quality}

Using the data loggers and hygrometers, the indoor air temperature and relative humidity changes were measured, and then the humidity ratios (i.e., absolute humidity) were calculated. Even though the auto-controlled centralized exhaust ventilation systems were operated with an $\mathrm{RH}$-sensor, it was important to use the humidity ratios to compare and to analyze the results of different cases due to relative humidity values, which were affected by moisture level as well as air temperature. Thus, this paper presents the resulting measured air temperature and relative humidity data as well as the calculated humidity ratio data for all cases.

Figures 5 and 6 show the resulting indoor air dry-bulb temperature and relative humidity changes of Case 1-1 and Case 1-2, respectively. As shown in Figure 5a, in Case 1-1, which the auto-controlled exhaust vent was not activated, it was found that the relative humidity in Bath 1 rouse to about $97 \% \mathrm{RH}$ 
during the shower, and then decreased to about $85 \% \mathrm{RH}$ when the bathroom door was opened after the shower. In addition, when the bathroom door opened after the shower, it was also observed that the moisture generated in Bath 1 distributed to Bedroom 1, thus that the humidity level of Bedroom 1 increased to around $80 \% \mathrm{RH}$. However, when using the auto-controlled exhaust vent in Bath 1, the humidity levels of Bath 1 and Bedroom 1 were controlled, even during and after the shower as shown in Figure 5b. This result of Case 1-2 implied that the moisture generated in the shower booth could be isolated in the shower booth due to the auto-controlled exhaust vent discharging the humid air to outside directly. Indeed, as shown in Figure 7, the relative humidity in the shower booth of Case 1-2 increased as much as Case 1-1 during the shower of $15 \mathrm{~min}$.

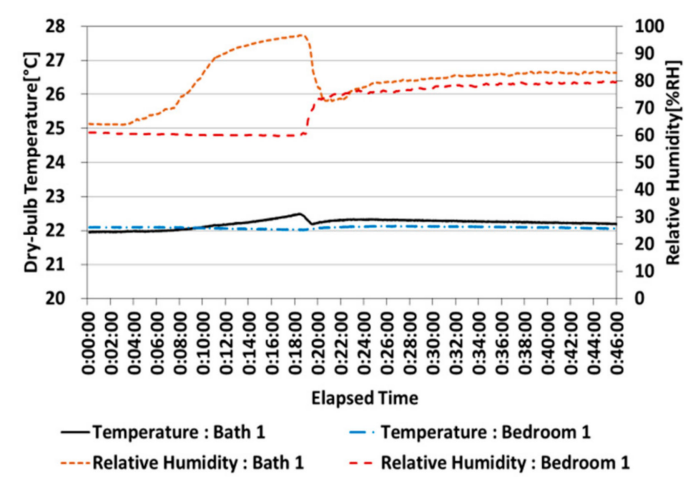

(a)

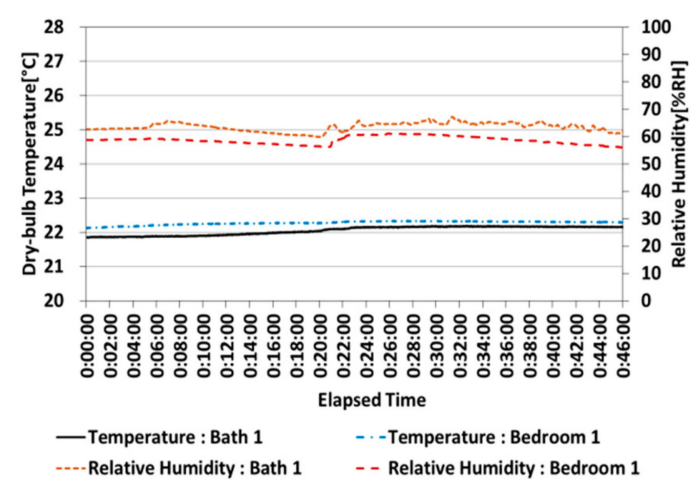

(b)

Figure 5. Temperature and relative humidity changes in different zones; (a) Case 1-1 and (b) Case 1-2.

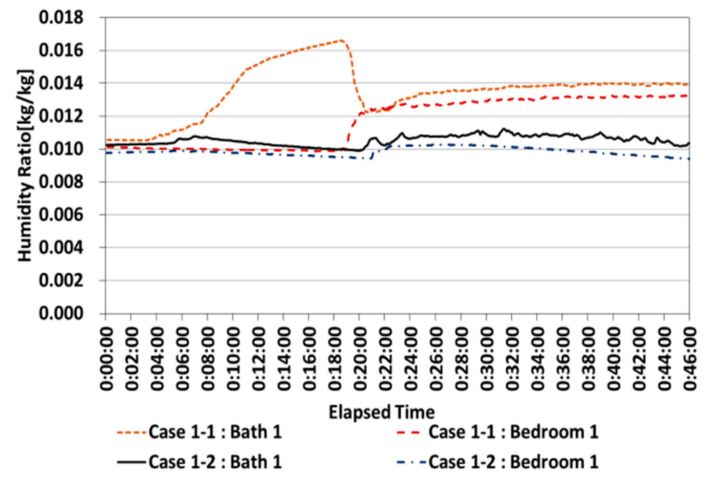

(a)

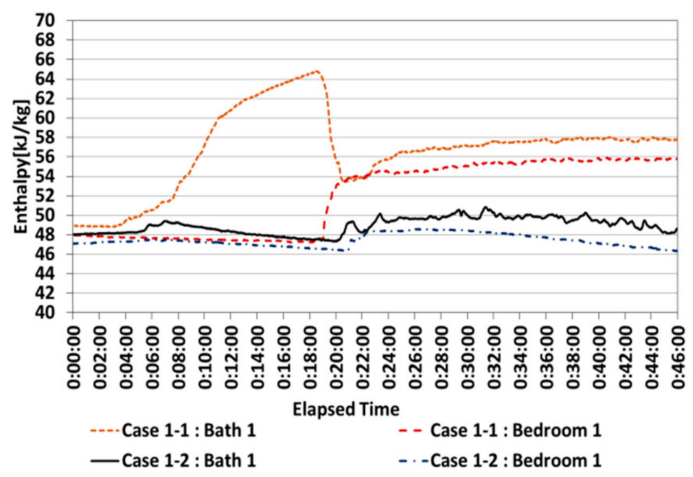

(b)

Figure 6. (a) Humidity ratio and (b) enthalpy changes in different zones of Case 1-1 and Case 1-2.

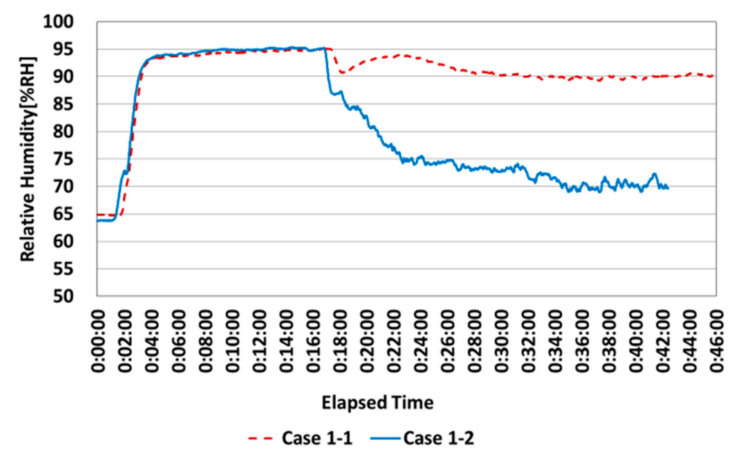

Figure 7. Relative humidity changes in the shower booth of Bath 1 for Case 1-1 and Case 1-2.

Meanwhile, in Figures 5 and 8, it was observed that the increased relative humidity level of Case 1-2 returned to the initial condition within $45 \mathrm{~min}$, while it took over $3 \mathrm{~h}$ for Case 1-1. In other words, 
since the auto-controlled exhaust vent discharged the humid air to the outside directly, the indoor humidity level of Case 1-2 was more quickly controlled than Case 1-1.

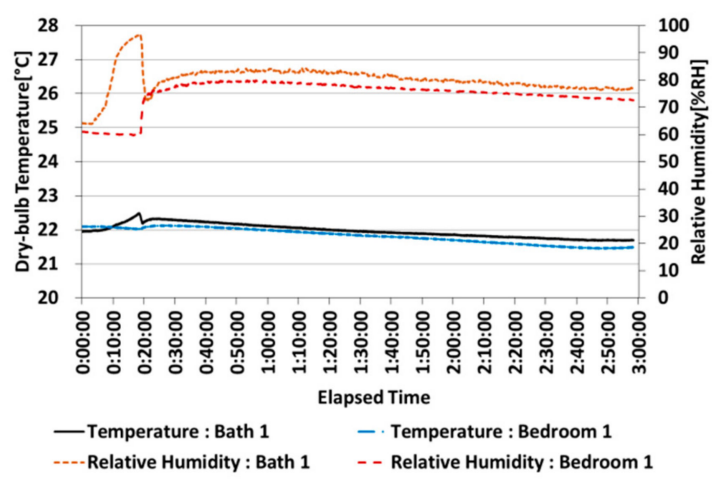

Figure 8. Temperature and relative humidity changes in Bath 1 and Bedroom 1 of Case 1-1.

To evaluate the effects of the auto-controlled exhaust vent in the Bath 2 with $80 \mathrm{~m}^{3} / \mathrm{h}$ on the changes of indoor air quality, two experiments were carried out. Figures 9 and 10 show the results of the experiments; Case 2-1 and Case 2-2. When the exhaust vent system was not operated, the moisture generated in the kitchen boiling $1 \mathrm{~L}$ water for $30 \mathrm{~min}$ was spread to other zones, and thus the temperatures and relative humidity levels of the zones increased. As shown in Figure 9, since the temperature in the kitchen increased because of the boiling water, the relative humidity in the kitchen increased relatively smaller than the other zones.

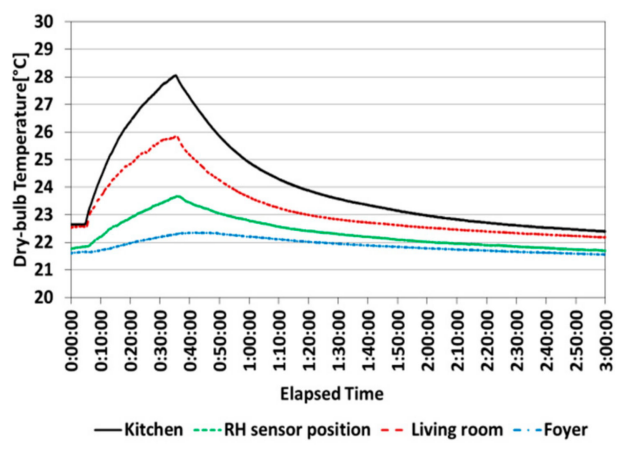

(a)

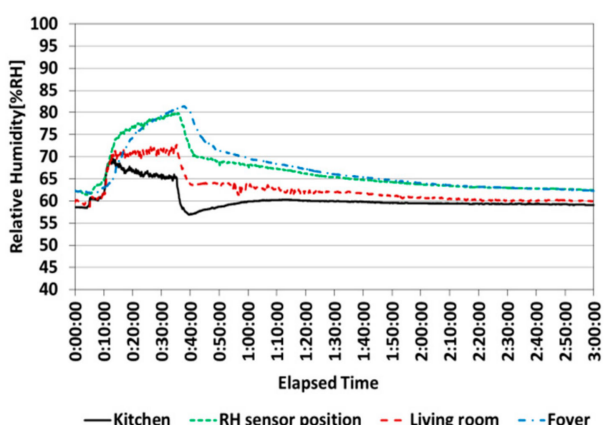

(b)

Figure 9. (a) Temperature and (b) relative humidity changes in different zones of Case 2-1.

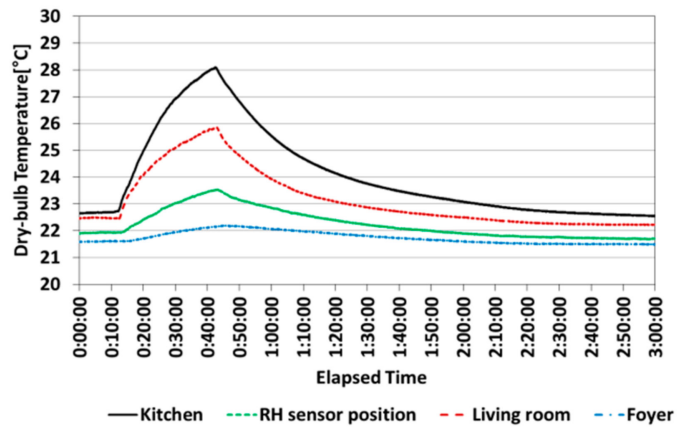

(a)

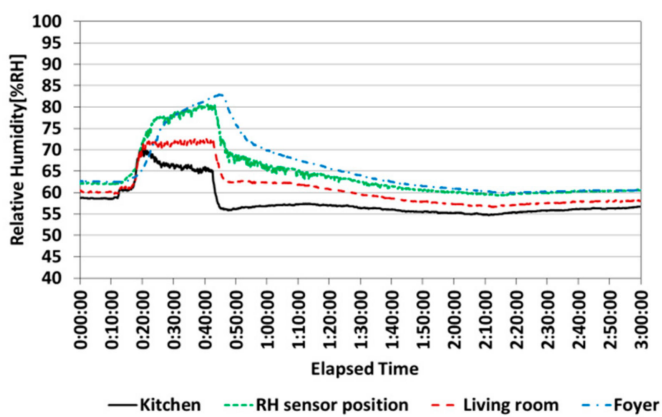

(b)

Figure 10. (a) Temperature and (b) relative humidity changes in different zones of Case 2-2.

However, as shown in Figure 11, the increasing rate of humidity ratio in the kitchen was higher than the other zones. In terms of humidity ratio changes in different zones shown in Figure 11, the result showed that much moisture generated from the kitchen was spread to other zones, especially to the 
foyer. Indeed, the percent difference in the maximum humidity ratio between the kitchen and the foyer was around $13 \%$. For this reason, the relative humidity of the foyer increased to about $80 \%$ $\mathrm{RH}$, and thus the possibilities of air quality issues, such as condensation or mold growth could be high. Besides, it took about $2.5 \mathrm{~h}$ for the increased humidity ratios of the zones to return to the initial condition by natural attenuation (Figure 11a), while when the RH-sensor based auto-controlled exhaust vent was activated, the time to return to the initial humidity ratios decreased to $1.5 \mathrm{~h}$ (Figure 11b).

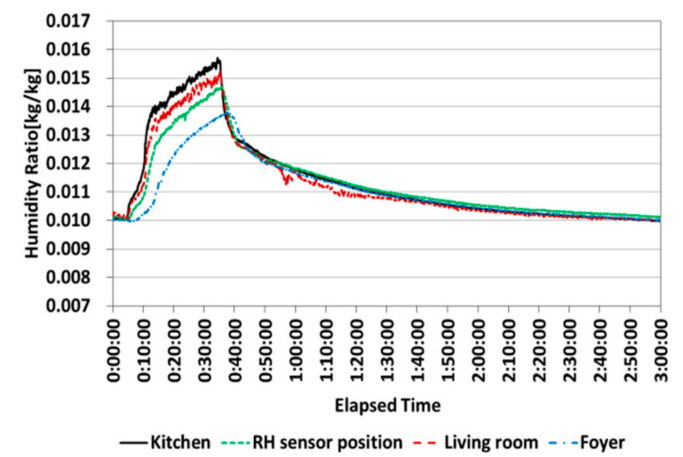

(a)

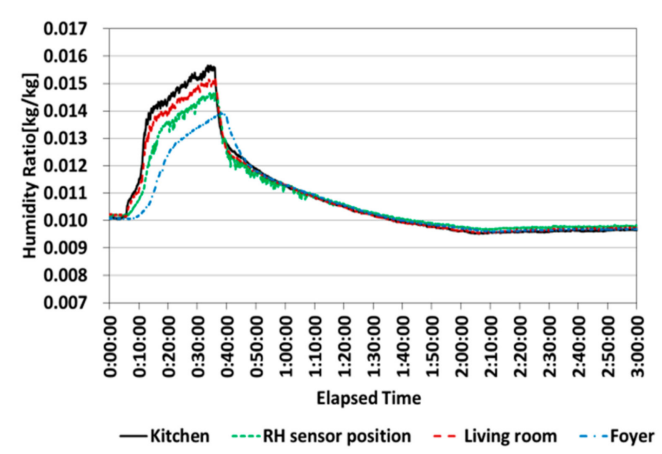

(b)

Figure 11. Humidity ratio changes in different zones of (a) Case 2-1, and (b) Case 2-2.

Meanwhile, it was found that the temperature, relative humidity, and max humidity ratios of Case 2-2 for different zones were almost the same to those of Case 2-1 (Figure 9 through Figure 11). This was because of the location of the RH sensor of the auto-controlled exhaust vent system, and also the location of the vent, which was placed in Bath 2. For these reasons, it took time for the RH-sensor to detect humid air distribution, and thus it allowed the moisture generated from the kitchen to spread out to other zones like Case 2-1. However, using the exhaust vent activated after the sensor detected the spread moisture from the boiling water in Case 2-2, humidity levels could be controlled faster than Case 2-1.

\subsection{Evaluation of Effects on Indoor Thermal Comfort}

In this section, the effects of the auto-controlled centralized exhaust ventilation systems on the thermal comfort level were evaluated. Predicted Mean Vote (PMV) and Predicted Percentage Dissatisfied (PPD) methods have been widely used around the world to measure thermal comfort [6-8]. This is the reason that this study employed the PMV and PPD methods to evaluate the effects of the auto-controlled centralized exhaust ventilation systems on indoor thermal comfort. The PMV and the PPD calculation processes employed in this study were based on the American Society of Heating, Refrigerating and Air-Conditioning Engineers (ASHRAE) Standard 55-2010. By the way, since the calculation of the PPD relies on the PMV values in accordance with Equation (1), it was necessary to calculate the PMV values first. According to the PMV model shown in Equation (2), indoor thermal comfort can be evaluated quantitatively.

$$
\begin{gathered}
\mathrm{PPD}=100-95 \cdot \mathrm{e}^{-\left(0.0335 \cdot \mathrm{PMV}^{4}+0.2179 \cdot \mathrm{PMV}^{2}\right)}, \\
\mathrm{PMV}=\left(0.303 \cdot \mathrm{e}^{-0.036 \cdot \mathrm{M}}+0.028\right) *\left[(\mathrm{M}-\mathrm{W})-\mathrm{H}-\mathrm{E}_{\mathrm{C}}-\mathrm{C}_{\mathrm{res}}-\mathrm{E}_{\mathrm{res}}\right],
\end{gathered}
$$

M: Metabolic rate $\left[\mathrm{W} / \mathrm{m}^{2}\right]$

W: Effective mechanical power $\left[\mathrm{W} / \mathrm{m}^{2}\right]$

$\mathrm{H}$ : Sensitive heat losses

$E_{c}$ : Heat exchange by evaporation on the skin

$C_{\text {res: }}$ : Heat exchange by convection in breathing

$\mathrm{E}_{\mathrm{res}}$ : Evaporative heat exchange in breathing. 
The individual heat flows in Equation (2) depend on several parameters; air temperature, humidity level, air velocity, mean radiant temperature (MRT), and two human parameters such as metabolic rate and clothing insulation rate. The assumptions related to these parameters made for this study are presented in Table 7 based on ASHRAE Standard 55-2010 and other reference research [9-11,24-32]. Especially, according to some research, it has been assumed that the MRT can be equal to the indoor air temperature, especially for the indoor thermal studies because the calculation of the MRT was complicated as well as the differences of wall surface temperatures and radiant fluxes were not significant [26-32].

Table 7. Input values of key parameters for the predicted mean vote (PMV) calculation.

\begin{tabular}{ccc}
\hline Parameter & Activity & Input Value \\
\hline Metabolic Rate & Standing, relaxed & Met $=1.2$ \\
\hline Clothing Insulation value & Typical winter indoor clothing & $\mathrm{Clo}=1.0$ \\
\hline Indoor Air Speed & No local air speed control & $\mathrm{V}=0.1 \mathrm{~m} / \mathrm{s}$ \\
\hline Operative Temperature $\left(\mathrm{T}_{\mathrm{o}}\right)$ & $\mathrm{T}_{\mathrm{o}}=\mathrm{f}\left(\mathrm{MRT}, \mathrm{T}_{\text {in }}\right)$ & $\mathrm{T}_{\mathrm{o}}=\mathrm{T}_{\text {in }}$ \\
& $\begin{array}{c}\text { MRT: Mean radiant temperature }\left[{ }^{\circ} \mathrm{C}\right] \\
\mathrm{T}_{\text {in }} \text { : Indoor air temperature }\left[{ }^{\circ} \mathrm{C}\right]\end{array}$ & \\
\hline
\end{tabular}

In Figure 6, it was found that the enthalpy changes of Case 1-2 were much lower than those of Case 1-1 in both Bath 1 and Bedroom 1. In addition, the time to return to the initial enthalpy of Case 1-2 was faster than that of Case 1-1. These results were consistent with the relative humidity changes presented in Figure 5. As aforementioned, the reason for this result was due to the auto-controlled exhaust vent discharged outside directly with the hot and humid air generated from the shower. However, as shown in Figure 12, there were no significant differences in enthalpy changes between Case 2-1 and Case 2-2, even though the time to return to the initial condition of Case 2-2 was faster than that of Case 2-1 due to the operation of the auto-controlled exhaust vent. As aforementioned, this was due to the location of the $\mathrm{RH}$-sensor that activated the exhaust vent. For this reason, before the exhaust vent was activated, the humid air was spread to other zones already and the amount of humid air was significant.

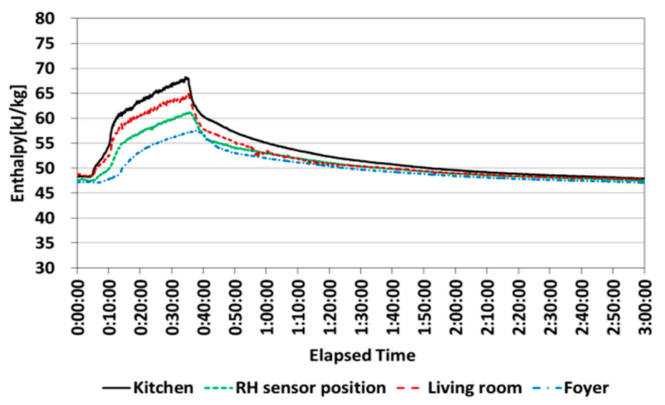

(a)

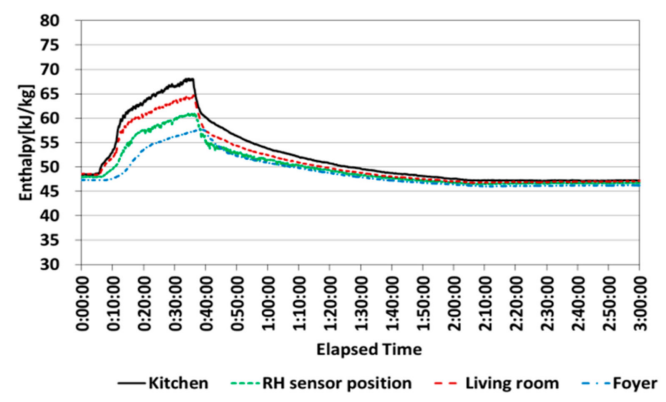

(b)

Figure 12. Comparison of enthalpy changes in different zones between (a) Case 2-1 and (b) Case 2-2.

Based on the PMV and the PPD methods, and on the resulting enthalpy changes presented in Figures 6 and 12, the effects of using the auto-controlled centralized exhaust vent on indoor thermal comfort could be evaluated. According to the ASHRAE Standard 55-2010, the acceptable thermal environment for general comfort could be defined using the PMV and the PPD values as presented in Table 8. And Figures 13 and 14 present the resulting PMV and PPD results of Case 1-1 and Case 1-2, and Case 2-1 and Case 2-2. 
Table 8. Acceptable thermal environment for general comfort [15].

\begin{tabular}{cc}
\hline PPD & PMV Range \\
\hline$<10$ & $-0.5<$ PMV $<+0.5$ \\
\hline
\end{tabular}

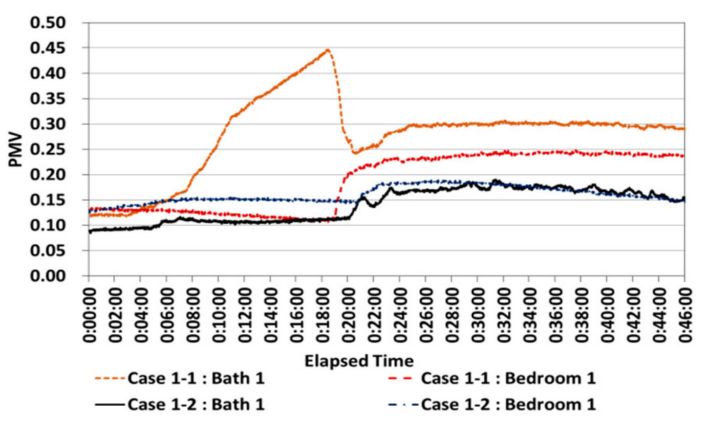

(a)

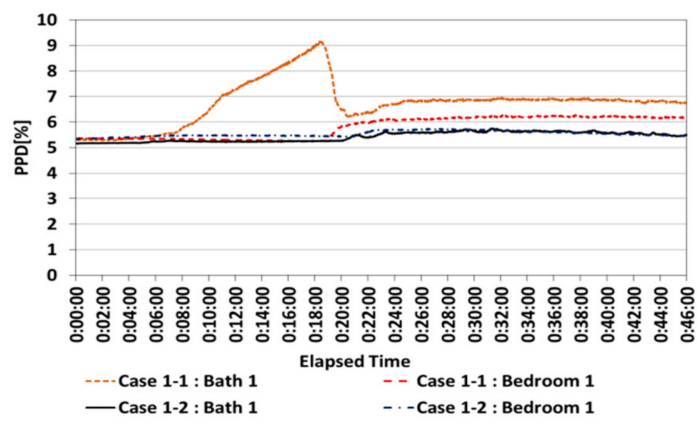

(b)

Figure 13. Changes in (a) PMV and (b) predicted percentage dissatisfied (PPD) in Bath 1 and Bathroom 1.

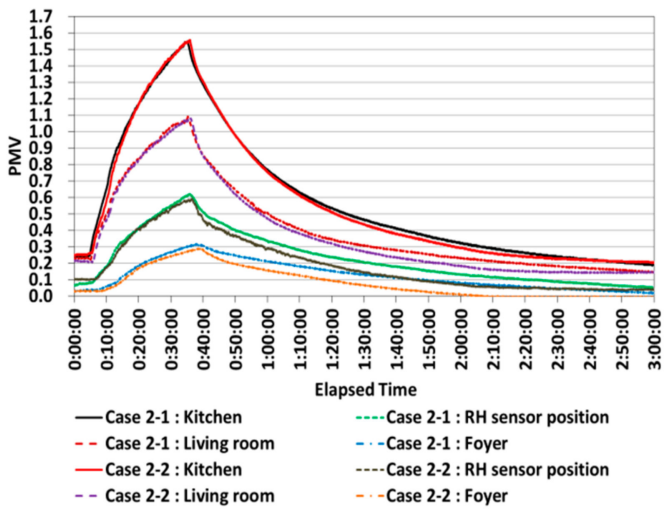

(a)

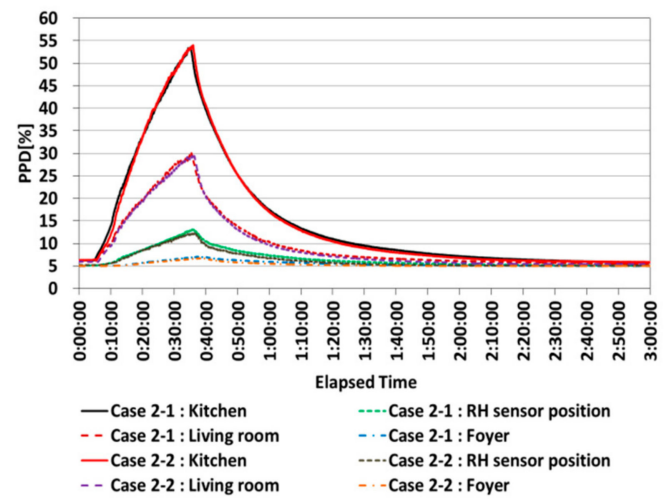

(b)

Figure 14. Changes in (a) PMV and (b) PPD in different zones.

With respect to Table 8, Case 1-1 and Case 1-2 were within the range of thermal comfort in both the PMV and the PPD methods. However, being consistent with the results in relative humidity, humidity ration, and enthalpy changes, the resulting PMV and PPD values were affected by humid air in Case 1-1. In other words, it could be expected that if the initial PMV and PPD values were slightly higher than the experimental conditions, the effects of the auto-controlled exhaust vent on thermal comfort acceptability would be obvious, showing that the exhaust vent system would keep the air quality as fresh.

Meanwhile, being consistent to the resulting enthalpy changes in Figure 12, it was found that there were not significant differences in the PMV and the PPD results between Case 2-1 and Case 2-2, especially when it came to the maximum values of PMV and PPD as shown in Figure 14. In both cases, the indoor air qualities in various zones became poor during boiling $1 \mathrm{~L}$ water for 30 min when the auto-controlled exhaust vent was operated. However, it was observed that because of using the exhaust vent, Case 2-2 returned to the initial PMV values faster than Case 2-1 by $30 \mathrm{~min}$ to $1 \mathrm{~h}$ depending on zones as shown in Figure 14a. In other words, due to the limited volume flow rate of exhaust vent in Bath 2 and the location of the RH-sensor, there could be a limit for the exhaust ventilation system to lower the humidity level rises in various zones during cooking in the kitchen, but this research proved that the exhaust vent system could return the indoor air quality to the initial comfort level faster than the base case. 


\section{Summary}

Table 9 presents the summarized results of a series of field tests performed in this research. As shown in Table 9, it was found that the humidity ratio rise of the cases using the auto-controlled centralized exhaust ventilation systems was lower than those of the cases without using the systems. In addition, since the humidity ratio levels of the cases with using the exhaust vents were lower, the stabilization times for these cases were shorter than those for the cases without using the exhaust vents.

Table 9. Summarized results of the field tests.

\begin{tabular}{|c|c|}
\hline Target Zone & Results \\
\hline $\begin{array}{l}\text { Bedroom } 1 \\
\text { and Bath } 1\end{array}$ & $\begin{array}{l}\text { - The moisture generated could be isolated due to using the } \\
\text { exhaust vent. } \\
\text { - Humidity levels and enthalpy returned to the initial condition due } \\
\text { to using exhaust vent faster than the base case } \\
\text { Both cases the air qualities were within the PMV } \\
\text { acceptability range. } \\
\text { If the initial enthalpy was higher, it could be expected that the } \\
\text { resulting PMV could be out of the thermal comfort range. }\end{array}$ \\
\hline Living room Kitchen Bedroom 1, 2, 3 & $\begin{array}{l}\text { - During boiling } 1 \mathrm{~L} \text { of water, the generated humid air was spread to } \\
\text { other zones and increased its humidity level and enthalpy. } \\
\text { Thus, as a result, the PMV and the PPD values were out of thermal } \\
\text { comfort ranges during cooking for both cases. } \\
\text { Using the auto-controlled exhaust vent, the time to return to being } \\
\text { within the comfort zone decreased by } 30 \text { min to } 1 \mathrm{~h} \text { from the base } \\
\text { case depending on the zones. }\end{array}$ \\
\hline
\end{tabular}

\section{Conclusions}

The purposes of this paper were (1) to evaluate performances of the RH-sensor-based auto-controlled centralized exhaust ventilation systems to control indoor air quality, and then (2) to evaluate the effect on thermal comfort after the occurrence of moisture increasing events. In order for performing evaluations, in this paper, a series of field tests were carried out for different target zones with different moisture generation events. As a result, it was observed that (1) the centralized exhaust ventilation system in Bath 1 could isolate the generated moisture within the shower booth and discharge the humid air to outside directly, (2) the stabilization times of the cases using the auto-controlled exhaust vent to return to the initial indoor air quality were faster than the cases not using the vent systems, and (3) the indoor thermal comfort was related to the indoor air quality, such as air temperature, humidity level, and enthalpy, and thus the thermal comfort levels of the cases with using the vent systems were within the thermal comfort range.

However, even though this paper investigated the effects of auto-controlled centralized exhaust ventilation systems on controlling indoor humidity levels and thermal comfort levels, there were limitations that could not be experimented in this paper with adjusting the parameters, such as volume flow rates of exhaust vents, various floor plans, various outdoor air conditions, and various occupants' activities. Besides, it was also another limitation of this paper that the RH-sensor locations associated with the operation of the auto-controlled system. Therefore, in the future, it is necessary to study the influences of these parameters on the performances of auto-controlled centralized exhaust ventilation systems.

The results presented in this paper can show the potential and the feasibility of the RH-sensor based auto-controlled centralized exhaust ventilation systems to maintain indoor air quality and to provide thermal comfort to multi-family residential buildings in South Korea.

Author Contributions: Conceptualization, B.C.K. and G.T.K.; methodology, B.C.K., J.P., S.K. and G.T.K.; formal analysis, B.C.K.; funding acquisition, G.T.K.; investigation, B.C.K. and G.T.K.; data curation, B.C.K. and G.T.K.; 
project administration, G.T.K., resources, B.C.K.; writing-original draft preparation, B.C.K.; writing-review and editing, G.T.K.; visualization, B.C.K.; supervision, G.T.K.

Funding: This research was financially supported by a grant (R201903007) from the Korea Land and Housing Institute.

Conflicts of Interest: The authors declare no conflict of interest.

\section{References}

1. Korea Energy Economics Institute. Yearbook of Energy Statistics; Korea Energy Economics Institute: Ulsan, Korea, 2018.

2. U.S. Energy Information Administration. Energy Consumption Estimates by Sector in 2018. Available online: https://www.eia.gov/consumption/ (accessed on 10 May 2019).

3. European Commission. Energy Performance of Buildings. Available online: https://ec.europa.eu/energy/en/ topics/energy-efficiency/energy-performance-of-buildings (accessed on 10 May 2019).

4. Moon, H.J. Humidity control in buildings for healthy environment. Rev. Archit. Build Sci. 2015, 59, 53-59.

5. Australian Building Codes Board. Condensation in Buildings-Handbook, 2nd ed.; Australian Building Codes Board: Canberra, Australia, 2014.

6. Arens, E.A.; Baughman, A.V. Indoor humidity and human health: Part II-Buildings and their systems. ASHRAE Trans. 1996, 102, 212-221.

7. Walker, I.S.; Sherman, M.H. Humidity implications for meeting residential ventilation requirements. In Proceedings of the ASHRAE Buildings X Conference-Thermal Performance of the Exterior Envelopes of Whole Buildings, U.S. Department of Energy, Oak Ridge National Laboratory, Atlanta, GA, USA, 2-7 December 2007.

8. TenWolde, A.; Pilon, C.L. The effect of indoor humidity on water vapor release in homes. In Proceedings of the ASHRAE Buildings X Conference-Thermal Performance of the Exterior Envelopes of Whole Buildings, Atlanta, GA, USA, 2-7 December 2007.

9. Fanger, P.O. Thermal Comfort, Analysis and Application in Environmental Engineering; Danish Technical Press: Copenhagen, Denmark, 1970.

10. Fanger, P.O. Assessment of man's thermal comfort in practice. Br. J. Ind. Med. 1973, 30, 313-324. [CrossRef] [PubMed]

11. ASHRAE. ANSI/ASHRAE Standard 55-2010-Thermal Environmental Conditions for Human Occupancy; The American Society of Heating, Refrigerating and Air-Conditioning Engineers: Atlanta, GA, USA, 2010.

12. Zhai, Y.; Zhang, Y.; Zhang, H.; Pasut, W.; Arens, E.; Meng, Q. Human comfort and perceived air quality in warm and humid environments with ceiling fans. Build. Environ. 2015, 90, 178-185. [CrossRef]

13. Vellei, M.; Herrera, M.; Fosas, D.; Natarajan, S. The influence of relative humidity on adaptive thermal comfort. Build. Environ. 2017, 124, 171-185. [CrossRef]

14. Wei, S.; Sun, Y.; Li, M.; Lin, W.; Zhao, D.; Shi, Y.; Yang, H. Indoor thermal environment evaluations and parametric analyses in naturally ventilated buildings in dry season using a field survey and PMVe-PPDe model. Build. Environ. 2011, 46, 1275-1283. [CrossRef]

15. Nguyen, A.T.; Singh, M.J.; Reiter, S. An adaptive thermal comfort model for hot humid South-East Asia. Build. Environ. 2012, 56, 291-300. [CrossRef]

16. Piasecki, M.; Fedorczak-Cisak, M.; Furtak, M.; Biskupski, J. Experimental confirmation of the reliability of fanger's thermal comfort model-Case study of a near-zero energy building (NZEB) office building. Sustainability 2019, 11, 2461. [CrossRef]

17. Wei, S.; Li, M.; Lin, W.; Sun, Y. Parametric studies and evaluations of indoor thermal environment in wet season using a field survey and PMV-PPD method. Energy Build. 2010, 42, 799-806. [CrossRef]

18. Raczkowski, A. Assessment of Perceived Air Quality for Selected Flat in the Residential Building, Environmental Engineering III, 1st ed.; Taylor \& Francis Group: London, UK, 2010.

19. Lim, Y.; Song, D. Development of water vapor control algorithm for preventing condensation in multi-residential building. In Proceedings of the 2015 Winter Conference of Society of Air-conditioning and Refrigerating Engineers of Korea, Seoul, Korea, 27 November 2015; pp. 283-286. 
20. Suh, H.S.; Ryu, S.R. An experimental research on the effect of the ventilation system on the condensation reduction. In Proceedings of the 2012 Autumn Conference of Architectural Institute of Korea, Gwangju, Korea, 25 October 2012; Volume 32, pp. 351-352.

21. Kim, Y.T.; Cho, W.J.; Rhee, K.N.; Hwang, M.K.; Lee, S.J.; Cha, J.H. Study on development of automatic control device of ventilation system to prevent indoor over-humidification in water. In Proceedings of the Korean Solar Energy Society Conference, Busan, Korea, 1-2 November 2012; Volume 32.

22. Nielsen, T.R.; Drivsholm, C. Energy efficient demand controlled ventilation in single family houses. Energy Build. 2010, 42, 1995-1998. [CrossRef]

23. Kim, G.T.; Chun, J.Y.; Kim, S.; Choi, K.S.; Park, G.Y. A Study on the Performance Evaluation and the Application Method of the Centralized Ventilation System; The Korea Land and Housing Institute: Daejeon, Korea, 2018.

24. Center for the Built Environment. CBE Thermal Comfort Tool. Available online: https://cbe.berkeley.edu/ project/thermal-comfort-tool/ (accessed on 10 July 2019).

25. Schiavon, S.; Hoyt, T.; Piccioli, A.L. Web application for thermal comfort visualization and calculation according to ASHRAE Standard 55. Build. Simul. 2014, 7, 321-334. [CrossRef]

26. Lin, Z.; Deng, S. A study on the thermal comfort in sleeping environments in the subtropics developing a thermal comfort model for sleeping environments. Build. Environ. 2008, 43, 70-81. [CrossRef]

27. Chaudhuri1, T.; Soh, Y.C.; Bose, S.; Xie, L.; Li, H. On assuming mean radiant temperature equal to air temperature during PMV-based thermal comfort study in air-conditioned buildings. In Proceedings of the IECON 2016-42nd Annual Conference of the IEEE Industrial Electronics Society, Florence, Italy, 24-27 December 2016.

28. Matzarakis, A.; Amelung, B. Physiological equivalent temperature as indicator for impacts of climate change on thermal comfort of humans, Seasonal Forecasts. Clim. Chang. Hum. Health 2008, 30, 161-172.

29. Kantor, N.; Unger, J. The most problematic variable in the course of human biometeorological comfort assessment-The mean radiant temperature. Cent. Eur. J. Geosci. 2011, 3, 90-100. [CrossRef]

30. Olesen, B.; Parsons, K. Introduction to thermal comfort standards and to the proposed new version of EN ISO 7730. Energy Build. 2002, 34, 537-548. [CrossRef]

31. Walikewitz, N.; Jnicke, B.; Langner, M.; Meier, F.; Endlicher, W. The difference between the mean radiant temperature and the air temperature within indoor environments: A case study during summer conditions. Build. Environ. 2015, 84, 151-161. [CrossRef]

32. Mayer, H.; Holst, J.; Dostal, P.; Imbery, F.; Schindler, D. Human thermal comfort in summer within an urban street canyon in central Europe. Meteorol. Z. 2008, 17, 241-250. [CrossRef] 